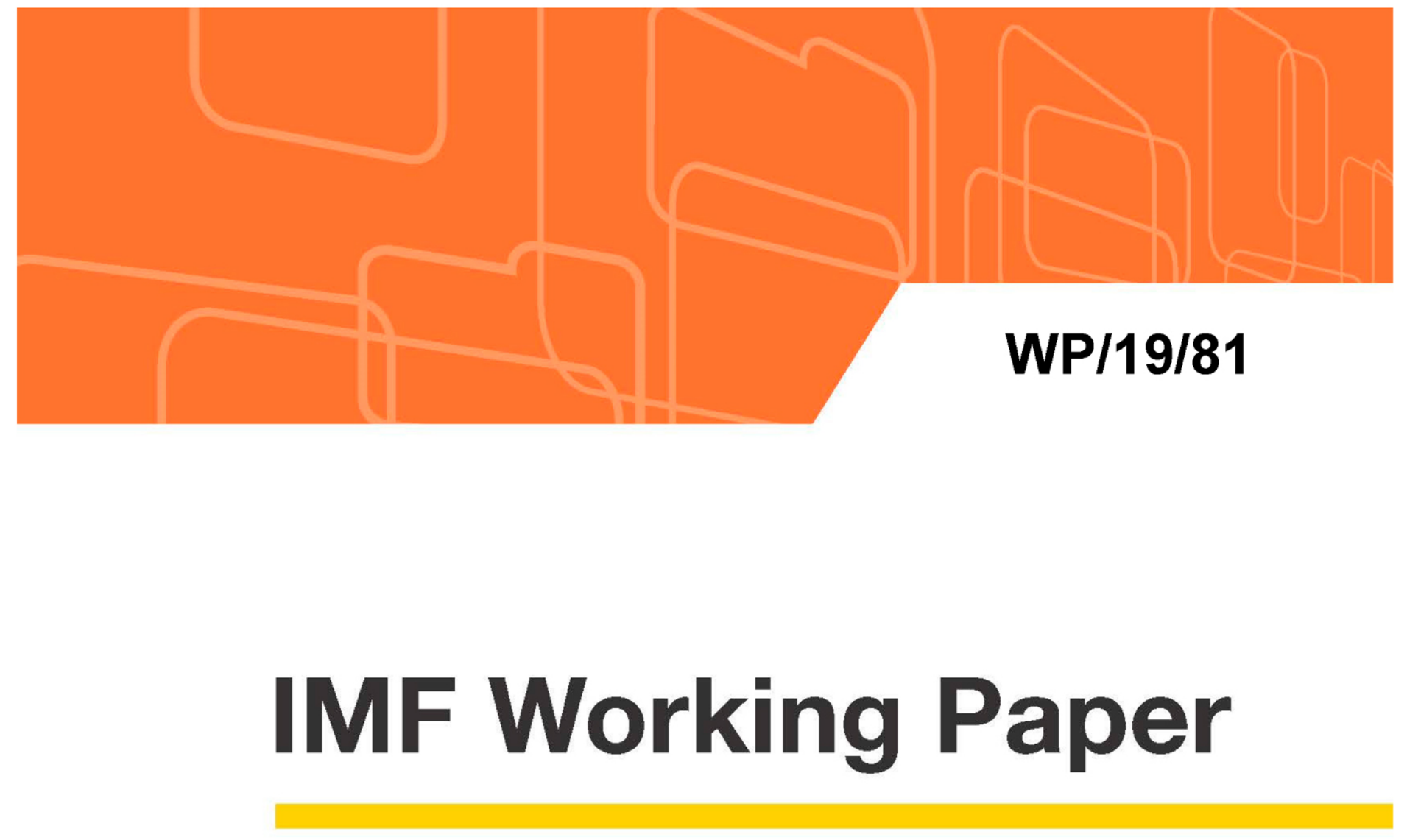

\title{
Indonesia's Public Wealth: A balance sheet approach to fiscal policy analysis
}

\author{
by Majdeline El Rayess, Avril Halstead, Jason Harris, \\ John Ralyea, and Alexander Tieman
}

IMF Working Papers describe research in progress by the author(s) and are published to elicit comments and to encourage debate. The views expressed in IMF Working Papers are those of the author(s) and do not necessarily represent the views of the IMF, its Executive Board, or IMF management. 


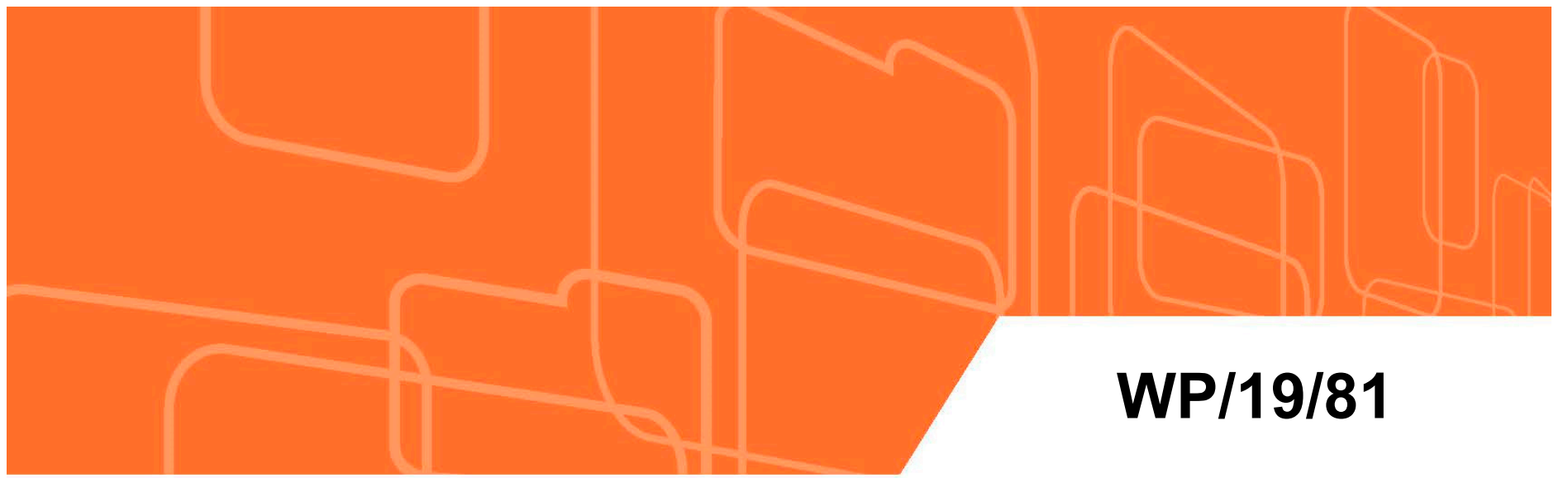

\section{IMF Working Paper}

\section{Indonesia's Public Wealth: A balance sheet approach to fiscal policy analysis}

by Majdeline El Rayess, Avril Halstead, Jason Harris, John Ralyea, and Alexander Tieman

IMF Working Papers describe research in progress by the author(s) and are published to elicit comments and to encourage debate. The views expressed in IMF Working Papers are those of the author(s) and do not necessarily represent the views of the IMF, its Executive Board, or IMF management. 


\title{
IMF Working Paper
}

Fiscal Affairs Department

Indonesia's Public Wealth:

\section{A balance sheet approach to fiscal policy analysis}

\section{Prepared by Majdeline EI Rayess, Avril Halstead, Jason Harris, John Ralyea, and Alexander Tieman ${ }^{1}$}

Authorized for distribution by Manal Fouad and Catherine Pattillo

April 2019

IMF Working Papers describe research in progress by the author(s) and are published to elicit comments and to encourage debate. The views expressed in IMF Working Papers are those of the author(s) and do not necessarily represent the views of the IMF, its Executive Board, or IMF management.

\begin{abstract}
Public sector balance sheets (PSBS) provide a framework for comprehensive and deep analysis of fiscal risks and policies. To illustrate these benefits, this paper shows how PSBS analysis can be applied to assess risks to Indonesia's public sector stemming from its public corporations. The paper also shows that the government's plans to finance a ramp-up in public investment with additional tax revenue increases both economic growth and public wealth.
\end{abstract}

JEL Classification Numbers: H00, H55, H60, H63, H68, H75, H81

Keywords: Public Sector Balance Sheet, Intertemporal Fiscal Balances, Public Investment, Indonesia.

Author’s E-Mail Addresses: melrayess@imf.org, avril.halstead@gmail.com, jharris@imf.org,jralyea@imf.org, and atieman@imf.org

\footnotetext{
${ }^{1}$ This project was undertaken in conjunction with the IMF's October 2018 Fiscal Monitor on Public Sector Balance Sheets. We are very grateful to Keiko Honjo for modeling the different fiscal policy scenarios in the paper. We would like to thank participants in a workshop held at the IMF in March 2018 and those who provided feedback following a presentation of the paper at the $2018 \mathrm{IMF} /$ World Bank Annual Meetings. We would also like to thank Joni Mayfield and Haile Meron for excellent editorial support. The paper was written while Ms. Halstead was an employee of the IMF.
} 


\section{Contents}

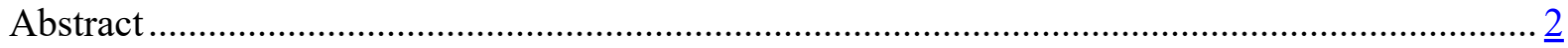

I. Introduction ..................................................................................................... 4

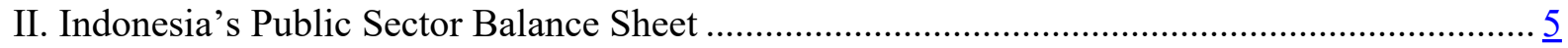

III. An Analysis of Public Corporations .......................................................................... 7

IV. Policy Scenario Analysis Using the Intertemporal Balance Sheet ...................................... 14

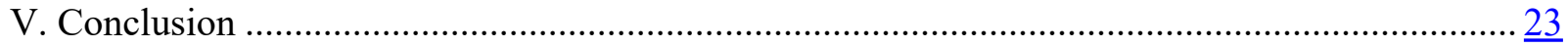

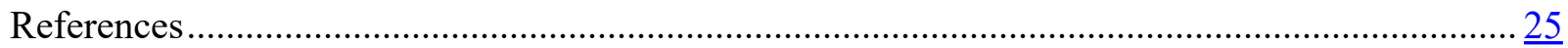

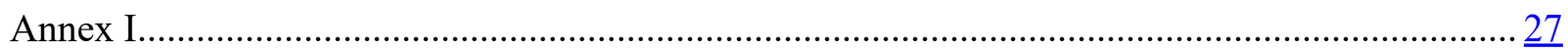

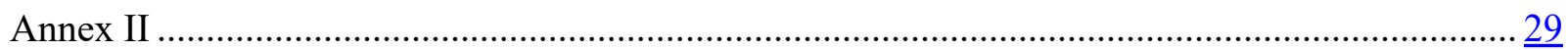

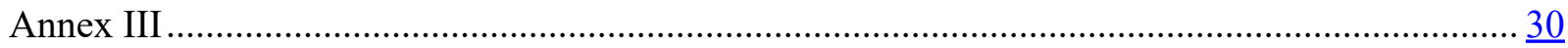

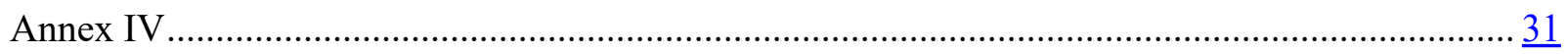

\section{Boxes}

Box 1. Key Indicators for Conducting an Initial, High-Level Assessment of Financial Soundness of Non-financial Public Corporations ............................................ 11

Box 2. Key Indicators for Assessing Financial Soundness of Public Banks ............................... 12

\section{Figures}

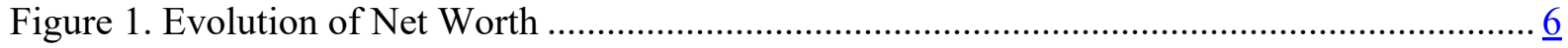

Figure 2. Net Worth Evolution by Activities .......................................................................... $\mathbb{7}$

Figure 3. Public Corporation Assets ............................................................................. $\underline{8}$

Figure 4. Public Sector Liabilities by Sector...................................................................... $\underline{8}$

Figure 5. General Government Financial Support to Public Corporations .................................... $\underline{8}$

Figure 6. Equity of Largest Public Corporations .................................................................... $q$

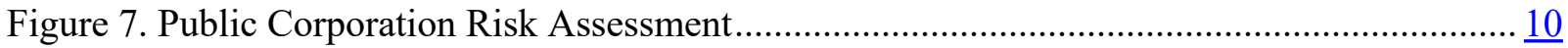

Figure 8. Implicit Cost of the Largest Public Corporations ..................................................... 13

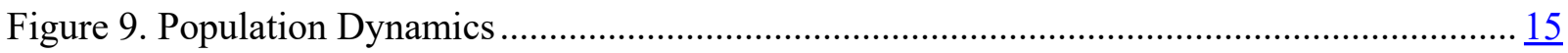

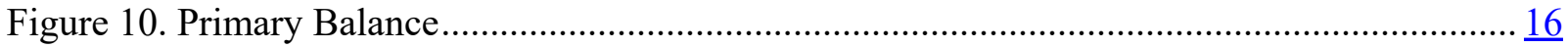

Figure 11. Public Sector Inter-temporal Net Worth ............................................................... 16

Figure 12. Future Revenues and Expenses, 2023 ............................................................. 17

Figure 13. General Governmnet Tax Revenue................................................................. 19

Figure 14. General Governmet Real Capital Stock .................................................................. 19

Figure 15. Impact of a Tax-financed Investment ................................................................. 21

Figure 16. Change in Public Sector Net Worth from Higher Investment .................................. 21

Figure 17. Real GDP Level ...................................................................................... 23

\section{Tables}

Table 1. Public Sector Balance Sheet ................................................................................ $\underline{5}$

Table 2. Sensitivity of Baseline Intertemporal Net Worth................................................... 18

Table 3. Consolidated Intertemporal Public Sector Net Worth in 2023 ...................................... 22

Annex II. Table 1. 2016 Indonesia Public Sector Balance Sheet ............................................. 29

Annex III. Table 1. Indonesia: Large Public Corporations Information....................................... $\underline{30}$

Annex IV. Table 1. Indonesia Public Sector Balance Sheet: Baseline Assumptions ...................... $\underline{31}$ 


\section{INTRODUCTION}

Public sector balance sheets (PSBSs) provide a framework for comprehensive and indepth analysis of fiscal risks and policies. A country's PSBS gives a complete picture of the government's assets and liabilities, some of which receive scant attention in standard analysis. It also extends the perimeter of coverage beyond the general government to the entire public sector including public corporations (state-owned enterprises). These PSBS attributes allow for a richer assessment of fiscal risks and the impact of fiscal policy on public net worth than standard fiscal policy analysis, which tends to focus on general government deficits and debts.

Indonesia's large and diverse public sector offers fertile ground for PSBS analysis. The public sector is sizable, with total assets of 166 percent of GDP in 2016. Financial and nonfinancial public corporation assets comprise a third of total assets and natural resources another fifth. On the liability side, total public sector liabilities were 73 percent of GDP in 2016 , compared to general government gross debt of 28 percent of GDP. The gradual depletion of mineral wealth has led to a steady erosion in Indonesia's static net worth from 148 percent of GDP in 2010 to 93 percent in 2016.

The public sector balance sheet framework can serve to highlight potential vulnerabilities associated with Indonesia's public corporations. In Indonesia, public corporations account for two-thirds of unconsolidated public sector liabilities. Potential vulnerabilities can encompass liquidity, profitability, and solvency concerns. In 2016, Indonesia's public banks posed a moderate fiscal risk, while the fiscal risk associated with some of the nonfinancial public corporations such as the electric utility company were higher. In aggregate, the implicit costs associated with non-financial public corporations' activities in Indonesia have trended upward.

Extending PSBS analysis to include the net present value of all future fiscal flows allows for policy scenario analysis. Including future revenues is important as the power to tax is the largest asset of most states. Future expenditures also need to be included and appropriately reflect any future aging pressures. ${ }^{2}$ While the intertemporal balance sheet provides the most comprehensive view on public finances, it obviously involves many assumptions (e.g., in constructing the future fiscal path). It is therefore subject to considerably more uncertainty than the static balance sheet. It lends itself, however, to scenario analysis of different future fiscal paths and therefore the quantification of policies' impact on fiscal sustainability.

For example, the public sector's intertemporal balance sheet can provide a more complete assessment of implications of public investment. In Indonesia, the government is

\footnotetext{
${ }^{2}$ Future payment streams on already existing public pension liabilities (which are included in the static balance sheet) need to be excluded from expenditures to avoid double counting. However, expenditures need to include payments for pension liabilities built up in the future.
} 
developing a comprehensive medium-term revenue strategy (MTRS) to raise revenue and plans to use part of it to finance a significant upgrade of infrastructure. PSBS analysis highlights the fact that tax-financed public investment leads to an accumulation of public sector assets, which in turn support a permanently higher real GDP. The analysis further illustrates how the policy package improves public wealth over the medium term.

The paper is organized as follows. Section II provides an overview of Indonesia's PSBS and its components as of end-2016. Section III, discusses the nature and financial situation of Indonesia's largest public corporations and provides a risk assessment of them. We then turn to using the PSBS to assess the impact of a tax-financed investment surge on Indonesia's GDP and its public wealth in Section IV. The last section concludes.

\section{Indonesia's Public Sector Balance Sheet}

Indonesia's public sector had significant assets and a positive net worth ${ }^{\mathbf{3}}$ in $\mathbf{2 0 1 6}$ (Table 1). Public sector assets were large, at close to 166 percent of GDP 4 , while liabilities amounted to 73 percent of GDP. Non-financial assets accounted for 70 percent of total assets, out of which the stock of natural resources comprised more than half (Annex I explains the methodology used to value natural resource reserves). On the financial assets side, debt securities and loans were the largest components. Annex II provides a detailed balance sheet.

Table 1. Public Sector Balance Sheet

(Percent of GDP)

\begin{tabular}{|l|r|r|r|r|}
\hline \multirow{2}{*}{2016} & \multirow{2}{*}{$\begin{array}{c}\text { General } \\
\text { Government }\end{array}$} & \multicolumn{2}{|c|}{ Public Corporations } & \multirow{2}{*}{ Pulic Sector } \\
\cline { 3 - 4 } & Non-Financial & Financial & \\
\hline Total assets & 123.8 & 26.3 & 39.6 & 165.6 \\
\hline of which: Nonfinancial assets & 95.8 & 20.0 & 1.0 & 116.8 \\
Financial assets & 28.0 & 6.4 & 38.6 & 48.8 \\
Total liabilities & 31.3 & 26.3 & 39.6 & 73.1 \\
of which: Debt securities & 23.0 & 2.4 & 2.3 & 23.0 \\
\hline Net Financial Worth & -3.3 & -20.0 & -1.0 & -24.3 \\
Net Worth & 92.5 & 0.0 & 0.0 & 92.5 \\
\hline
\end{tabular}

On the liabilities side, the balance sheet illustrates the important role of the public financial corporations, mainly deposit-taking corporations. Currency and deposit obligations were significant (25 percent of GDP) in 2016, reflecting a large public banking sector that comprises over half of total financial assets. Also, debt securities - the primary

\footnotetext{
${ }^{3}$ The table shows a net worth of zero for public corporations. This is because equity value is included in the total liabilities, and therefore, the balance will appear as zero. For example, in 2016, the total equity of financial public corporations was positive of 5.8 percent of GDP.

${ }^{4}$ For a full comparison of the balance sheet of Indonesia with other countries, please refer to the IMF Fiscal Monitor, October 2018 "Managing Public Wealth" https://www.imf.org/en/Publications/FM/Issues/2018/10/04/fiscal-monitoroctober-2018/.
} 
source of funding for the central government - amounted to 23 percent of GDP. The remaining instruments were relatively small. Specifically, pension liabilities amounted to just 2 percent of GDP.

However, net worth has declined since at least 2010. It dropped from 148 percent of GDP to 93 percent of GDP between 2010-16, as assets fell from 205 percent of GDP to 166 percent of GDP.

The decrease Figure 1. Evolution of Net Worth was mainly due (Percent of GDP)

to the loss in value of mineral resources ${ }^{5}$ while most of the remaining asset instruments were stable over that period. On the other hand, total liabilities of the public sector increased

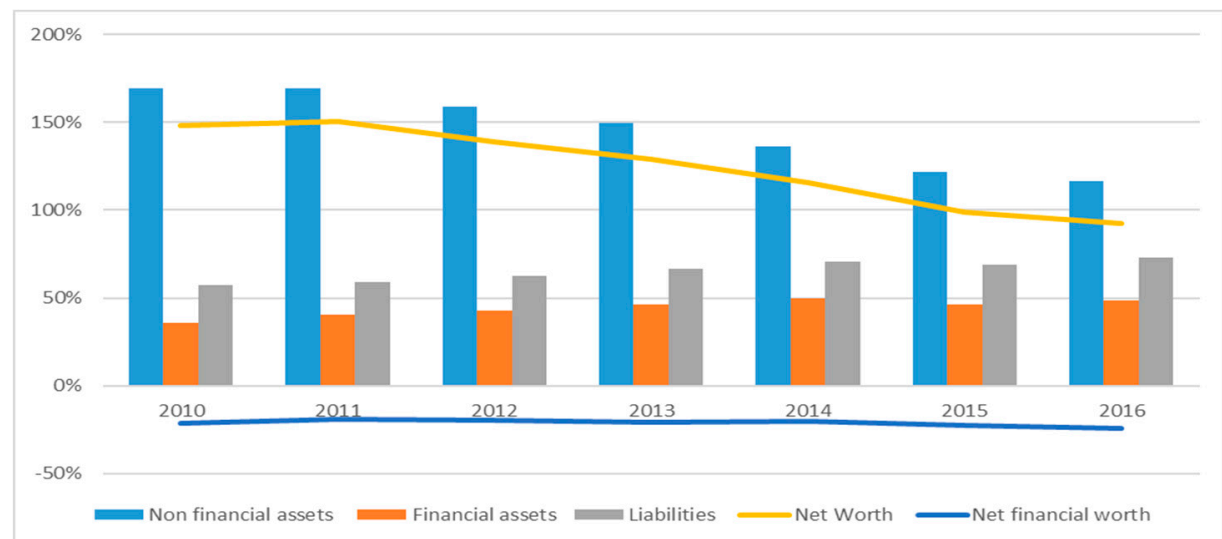
from 57 percent of GDP in 2010 to 73 percent of GDP in 2016 mainly due to increases of debt securities ( 9 percent of GDP), currency and deposits in the financial public corporations ( 3 percent of GDP) and the value of equity in public corporations (4 percent of GDP (Figure 1). Net financial worth has slightly deteriorated over the years going from negative 21 percent of GDP in 2010 to negative 24 percent of GDP in 2016.

Changes in net worth reflect operating activities and valuation changes. In some years, the public sector net operating balance (revenue less expenses) was the main contributor to changes in total net worth, while in other years other economic flows (valuation changes and other volume changes) affected the net worth substantially. For example, in 2016, total revenue was 25 percent of GDP, while total expenditures (expenses and net investment in non-financial assets) were 27 percent of GDP, generating a net operating deficit of 2 percent and lowering net worth by a similar amount as the change in other economic flows was close to zero. Conversely in 2011, the net operating balance was almost balanced while the total of other economic flows was close to 20 percent of GDP.

\footnotetext{
${ }^{5}$ The values of Indonesia's mineral resources were estimated by IMF staff. See Annex 1 for the methodology used to calculate the value of mineral resources.
} 
The relationship between the various subsectors of the public sector is strong. This is evident in the high amount of consolidation $^{6}$ which, in 2016, comprised 24 percent of GDP. This highlights the strong interlinkages among the various subsectors of the public sector. For example, most of the public corporations and general government have their bank accounts either in public banks or the central bank (around 22 percent of total deposits are held by the central bank or public banks) which amounted in a consolidation of around 5 percent of GDP of total currency and deposits in 2016. Also, the control of the government is dominant, owning on average more than 71 percent of total equity of the public corporations. This has resulted in 2016 in the consolidation of the cross holding of equity of a total of 14 percent of GDP.

\section{An Analysis of Public Corporations}

\section{A. Overview}

\section{Public corporations are a significant component of Indonesia's public sector balance} sheet. Indonesia has 118 public corporations owned by the central government that comprise more than 35 percent of unconsolidated public sector assets. The total assets of both financial and non-financial corporations grew from 2010 to 2016 (Figure 3). On the other side of the ledger, the liabilities of the public corporations accounted for 66 percent of GDP in 2016, above other emerging market countries, and financial public corporations account for more than 40 percent of unconsolidated public sector liabilities. Moreover, the aggregate balance sheet for public corporations in Indonesia is highly concentrated. The five largest companies, which are in either the financial or energy sectors, account for about half of all public corporation assets. While performance generally improved in 2016, public corporations cash flow constraints and debt pose a fiscal risk and absorb a significant amount of explicit and implicit government subsidies.

\footnotetext{
${ }^{6}$ Consolidation is the process of netting out the cross holding of assets and liabilities between the various subsectors of the public sector.
} 
Figure 3. Public Corporation Assets (Percent of GDP)

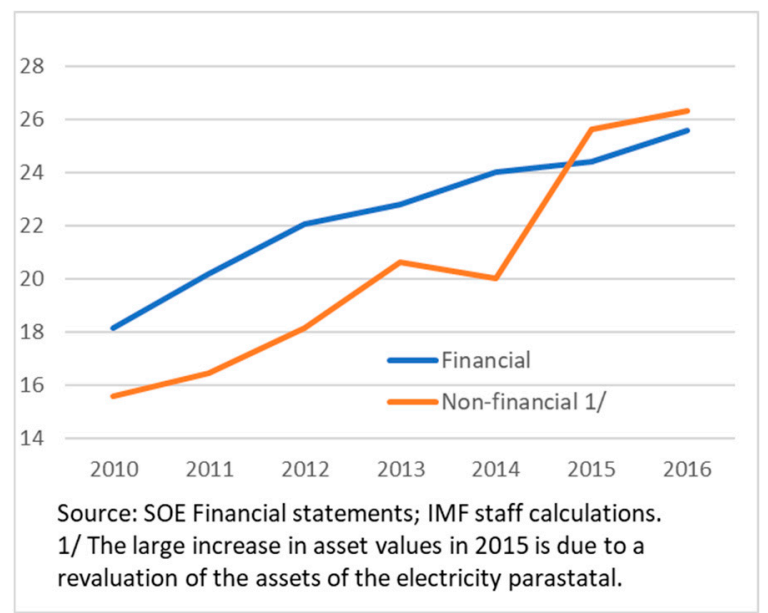

Figure 4. Public Sector Liabilities by Sector (Percent of total liabilities)

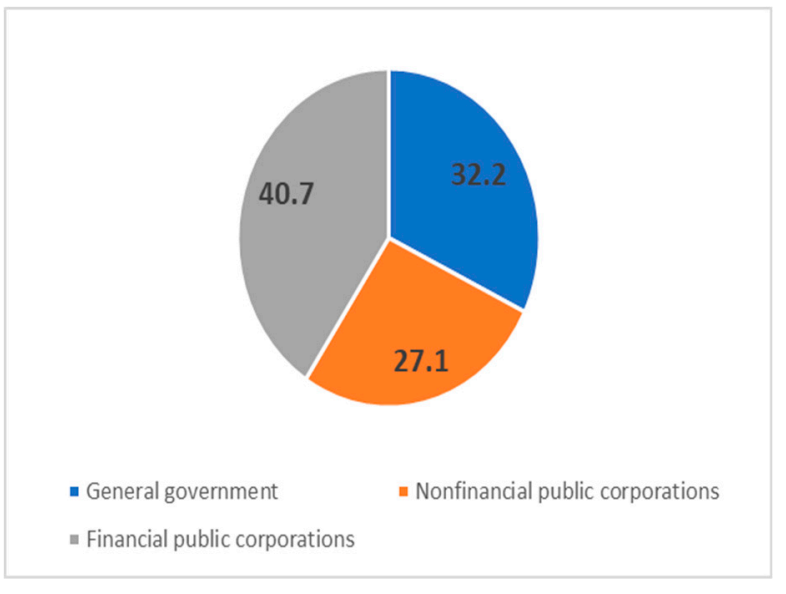

Source: IMF staff calculations.

Government financial support to public corporations has also been significant. Indonesia's public corporations receive significant government assistance, mainly through explicit and implicit subsidies, injection of equity, and capital transfers, though it has trended downward from 2012-16. In 2016, explicit state support amounted to 2.3 percent of GDP (Figure 5). Adding implicit costs of 13 of the largest public corporationsthe value of forgone profits from inefficient and noncommercial activities of public corporations ${ }^{7}$ would have boosted total state assistance to 3.3 percent of GDP in 2016. At

Figure 5. General Government Financial Support to Public Corporations (Percent of GDP)

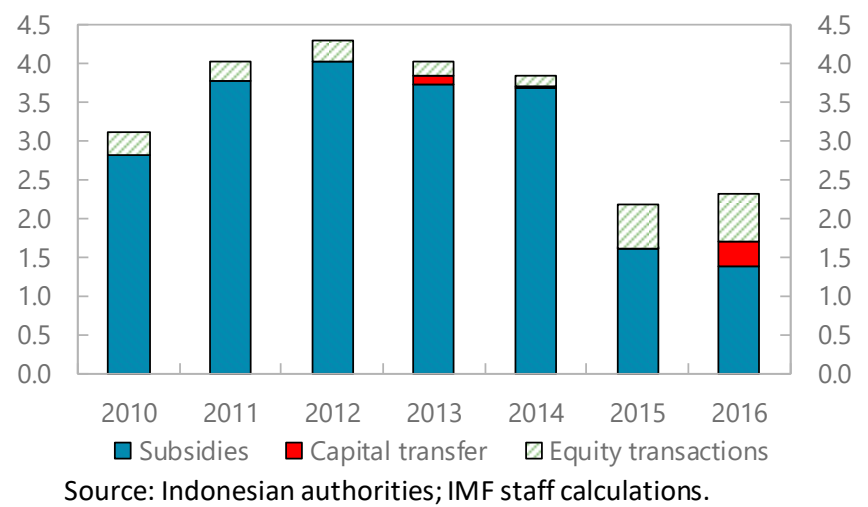
the same time, public corporations also make tax, interest, and dividend payments to the general government. These payments averaged about 1 percent of GDP from 2011-16.

\footnotetext{
${ }^{7}$ See below for a fuller description of implicit subsidies and their calculation.
} 


\section{Financial Performance}

Asset revaluation and a pickup in profitability have boosted public corporation equity. The analysis that follows focuses on 13 of the largest public corporations, which comprise 60 percent of total public corporations' assets. See Annex III for select financial information on the 13 corporations. From 2010-14, the aggregate growth of public corporations' equity was broadly in line with GDP growth. However, a revaluation of the electricity utility's (Perusahaan Listrik Negara (PLN)) assets in 2015 led to a spike in overall public corporation equity. In 2016, a further increase in equity relative to GDP was largely due to a pickup in profitability as public corporations generated net earnings of close to 1 percent of GDP, yielding an average return on equity (ROE) for public corporations of 9.3 percent.

Figure 6. Equity of Largest Public Corporations (Percent of GDP)

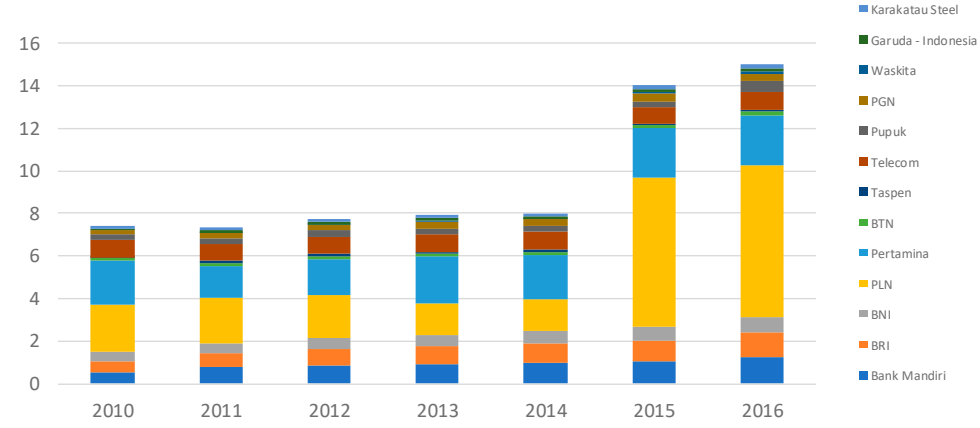

Source: Public corporation financial statements; IMF staff calculations.

However, broad equity trends mask divergent performance. Looking at individual SOEs, the average ROE of several banks (Bank Mandiri, Bank Rakyat Indonesia (BRI), Bank Negara Indonesia (BNI), Bank Tabungan Negara (BTN)), Pertamina, and Telecom exceeded the average for public corporations. However, most other companies generated negligible profits (in the range of 0-5 percent of equity), and Krakatau Steel made a loss.

Non-financial public corporations' debt levels are high relative to earnings, despite a recent improvement in gearing. Public corporation liabilities (excluding equity) fell from 63 percent of assets in 2014 to 45 percent in 2016, which was mainly attributable to the oneoff asset revaluation at PLN in 2015. ${ }^{8}$ More significantly, aggregate debt levels relative to earnings have been falling, indicating that the companies are better able to generate cash to service their debt. However, several of the major companies including Pupuk, Perusahaan Gas Negara (PGN), Waskita, Garuda and Krakatau Steel have liabilities exceeding 5 times EBITDA $^{9}$, suggesting there is a high risk that they may have difficulties servicing their debt (Standard \& Poor's Ratings Services 2013). In addition, the overall liquidity position is tight,

\footnotetext{
${ }^{8}$ On December 31, 2015, the PLN changed their accounting policy for certain classes of assets from the cost model to the revaluation model. The revaluation was conducted by an Independent Public Valuer who was selected through a tender process. Revaluation of land and power plants accounted for the bulk of the increase in fixed asset values, which more than doubled in nominal terms as a result of the revaluation.

${ }^{9}$ Earnings before Interest, Tax, Depreciation and Amortization.
} 
with an aggregate current ratio of 1.3 compared with a norm of $2 .{ }^{10}$ This implies that the nonfinancial public corporations may not have adequate buffers to weather challenges in the event of a liquidity crunch.

\section{Potential Fiscal Risk}

The public corporations constitute a potential fiscal risk, which the Indonesia authorities monitor. Based on a high-level risk assessment of the major public corporations, the financial condition of several non-financial public corporations in 2016 posed an elevated fiscal risk. (Box 1 and Box 2 set out the methodology used to make the high-level risk assessments of non-financial and financial public corporations, respectively, and Figure 7 provides a summary.) ${ }^{11}$ The outstanding liabilities of the high-risk entities amount to 6.5 percent of GDP in 2016. Given that total tax collections amount to 12 percent of GDP, this indicates that should any public corporation risk materialize, it could have a material impact on fiscal outcomes. For example, in the wake of the Asian crisis, the government had to inject cash equivalent to 4 percent of GDP to recapitalize PLN and recapitalize several public banks.
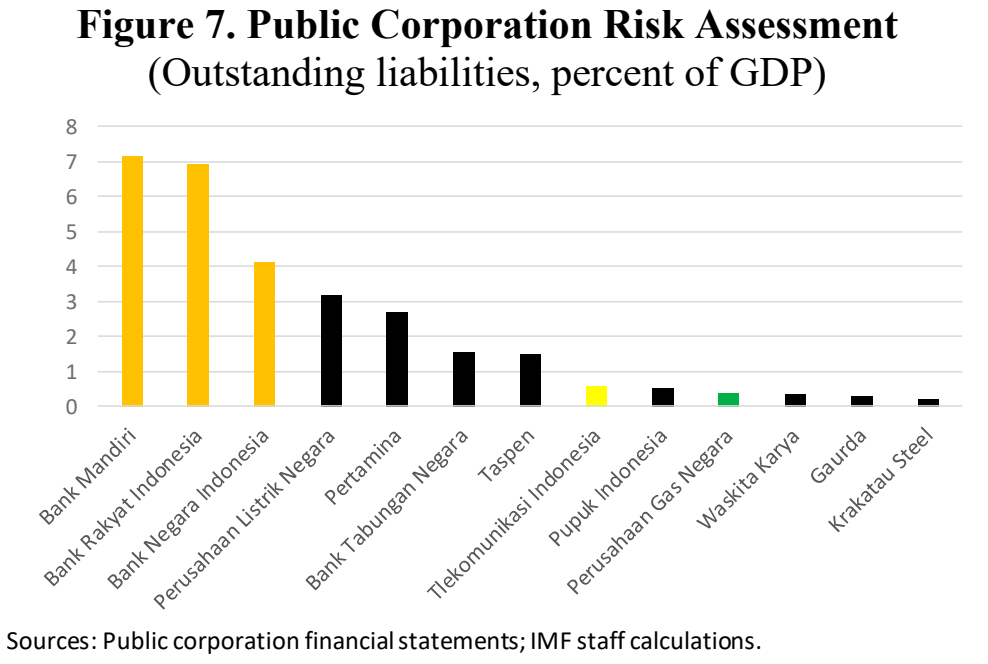

\section{The high-level} assessment indicates that large public banks posed a moderate fiscal risk in 2016. The four large public banks (Bank Mandiri, BRI, BNI, and BTN) posted an overall simple average ROE of 17.5 from 2012-16, with a lowest average ROE over that period of 12.6 percent for BTN. The banks, in general, had an

average regulatory capital to risk-weighted assets ratio slightly above 20 percent in 2016 (IMF, 2017). BTN's adequacy ratio was the lowest at 8.9 percent. $^{12}$ Around 75 percent of the

\footnotetext{
10 The current ratio is a liquidity ratio that measures a company's ability to pay obligations due within a year. It is the ratio of current assets (e.g., cash and cash equivalents, and accounts receivable) over current liabilities (liabilities payable within one year).

${ }^{11}$ The IMFs Fiscal Affairs Department has applied this same methodology in several countries: Namibia, South Africa, Georgia, Ukraine (and an earlier slightly different version in Egypt).

12 Tier 1 capital consists of common stock and retained earnings. Tier 2 capital also includes revaluation reserves, hybrid capital instruments and subordinated term debt, general loan-loss reserves, and undisclosed reserves.
} 
four banks' funding comes from deposits, which is a more stable source of funding than capital market funding but does expose the banks to significant asset-liability mismatches.

\section{Box 1. Key Indicators for Conducting an Initial, High-Level Assessment of Financial Soundness of Non-financial Public Corporations}

For the non-financial public corporations, the high-level assessment is based on the following four key financial indicators:

\section{Profitability}

- Return on equity: Determines the relationship between profit and equity and indicates whether the company is generating profits and whether these are in line with commercial rates of return. For loss making companies, it indicates how quickly the equity is being eroded.

\section{Solvency}

\begin{tabular}{|l|l|l|l|l|}
\hline$>15 \%$ & $8 \%-15 \%$ & $0 \%-8 \%$ & $-10 \%-0 \%$ & $<-10 \%$ \\
\hline
\end{tabular}

- Debt ratio: Determines the relationship of liabilities to assets and indicates whether the company is solvent (assets are larger than the liabilities) and the degree to which the company is leveraged. Highly leveraged companies have less financial flexibility.

\begin{tabular}{|c|c|c|c|c|}
\hline$<30 \%$ & $30 \%-$ & $50 \%-$ & $80 \%-$ & $>100 \%$ \\
& $50 \%$ & $80 \%$ & $100 \%$ & \\
\hline
\end{tabular}

- Debt to EBITDA: Determines the relationship between debt to profit and indicates the company's ability to service its debt from operating cash flows.

\section{Liquidity}

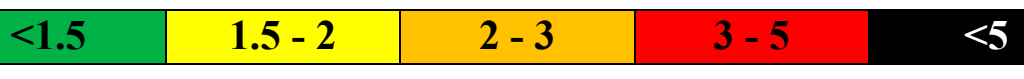

- Current ratio: Determines the relationship of current assets to current liabilities and indicates the company's ability to meet is short term liabilities using its short-term assets.

\section{\begin{tabular}{l|l|l|ll}
$>2$ & $1.5 \%-2$ & $1.2-1.5$ & $1-1.2$ & $<1$
\end{tabular}}

The overall rating was calculated based on the number of ratios that were rated in each category. However, if any indicator is rated black then the overall rating is black.

Sources: Standard \& Poor's Rating Services (2013) Corporate Methodology and staff analysis.

The fiscal risks associated with public corporations call for the close monitoring of their financial performance individually and in aggregate. Company financial statements permit the former and public sector balance sheets allow for the latter. Although the banks were rated as low risk, the large size of their outstanding liabilities relative to economy means that their financial position needs to be closely monitored to manage and mitigate the potential systemic risk they pose to the economy and the financial health of the public sector. This would also apply to the largest non-financial public corporations, particularly those that 
play a macro-critical role, i.e., where a disruption to their operations could have a systemic, negative impact on the economy (e.g., PLN or Pertimina). ${ }^{13}$

\section{Box 2. Key Indicators for Assessing Financial Soundness of Public Banks}

The high-level assessment is based on the following four key financial indicators:

Profitability

- Return on assets: Indicates whether the bank is generating profits. For loss making companies, it indicates how quickly the assets are being eroded.

\section{Capital adequacy}

\begin{tabular}{l|l|l|l|l}
$>10 \%$ & $5 \%-10 \%$ & $0 \%-5 \%$ & $-5 \%-0 \%$ & $<-5 \%$
\end{tabular}

- Capital adequacy ratio: Indicates whether the bank is solvent and the extent to which the bank has adequate capital reserves to absorb losses.

\begin{tabular}{|l|l|l|l|l}
\hline$>15 \%$ & $12 \%-15 \%$ & $10 \%-12 \%$ & $8 \%-10 \%$ & $<8 \%$
\end{tabular}

\section{Quality of the loan portfolio}

- Nonperforming loan ratio: Indicates the proportion of the loan portfolio which is non-performing, which can be an indication of the quality of the bank's credit assessment process.

\section{Liquidity}

\begin{tabular}{|c|c|c|c|c|}
\hline$<1 \%$ & $1 \%-2 \%$ & $2 \%-5 \%$ & $5 \%-10 \%$ & $>10 \%$ \\
\hline
\end{tabular}

- Loan to deposit ratio: Indicates the bank's reliance on its own deposits to make loans to customers, without outside borrowing and its exposure to a sudden reduction of liquidity in the capital markets

\begin{tabular}{|l|l|l|l|l|}
\hline$>100 \%$ & $80 \%-$ & $60 \%-80 \%$ & $50 \%-60 \%$ & $<50 \%$ \\
\hline
\end{tabular}

The overall rating is calculated based on the number of ratios that were rated in each category. However, if any indicator is rated black then the overall rating is black. Sources: Standard \& Poor's Rating Services (2011) Banks: Rating Methodology and Assumptions and staff analysis.

\section{B. Implicit Financial Costs of Public Corporations ${ }^{14}$}

\section{A public corporation reduces public wealth when its financial returns do not} compensate for the risks associated with its operations. This implicit cost can be measured as the difference between the return that comparable private companies generate

\footnotetext{
${ }^{13}$ More recent assessments of PLNs and Pertimina's financial condition reinforces the need for close monitoring of their financial situation. Moody's and Standard \& Poors in 2018 identified high leverage or the potential for an increase in leverage at PLN and Pertimina as key risks/challenges to their respective ratings of the companies. They also noted the ratings are dependent on continued government support for the companies.

${ }^{14}$ Implicit financial costs are broadly defined as the opportunity cost to the public sector of allocating public sector capital to public corporations on which the public corporation does not generate a sufficient return to cover the risk-adjusted cost of capital.
} 
and those generated by the public corporation. Several factors may cause public corporations to generate implicit costs. For example, public corporations may undertake non-commercial, quasi-fiscal activities on behalf of the government for which the government does not provide an explicit subsidy, incur leakages due to weak governance or oversight, occupy public land rent free, or simply be inefficient. These costs are in addition to the explicit subsidies noted above.

The implicit cost of Indonesia's public corporations trended upward during 2010-16 (Figure 8). The annual total implicit cost represents the weighted average of the annual implicit cost of each public corporation. The latter is calculated as the difference between the actual profit the corporation earned and the profit it would have earned if it generated a return on equity equivalent to the return of the Jakarta Composite (stock) Index (JCI). ${ }^{15}$ While limited as a proxy for sectoral (comparable company) returns, the JCI is an indicator of the opportunity cost of holding equity in a public corporation. The aggregate

Figure 8. Implicit Cost of the Largest Public Corporations (Percent of GDP)

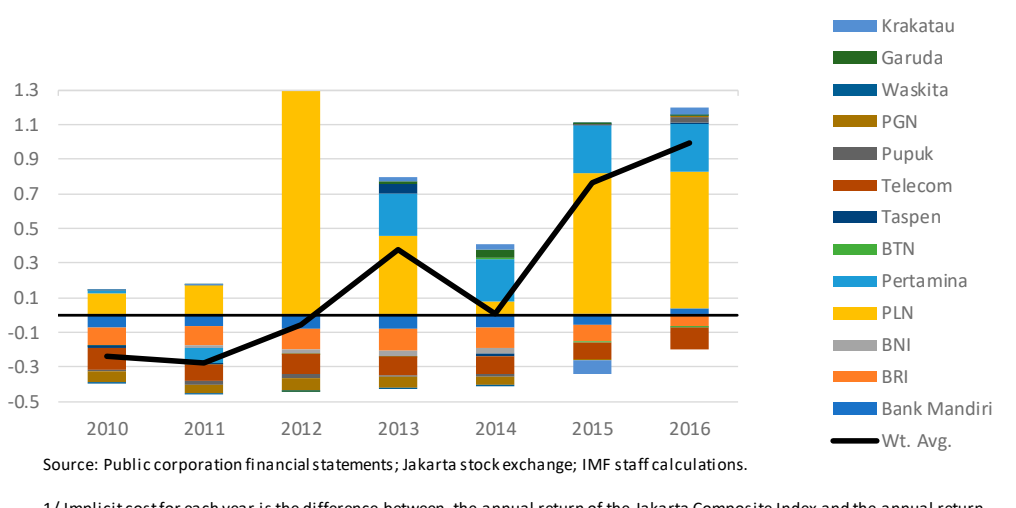

$1 /$ Implicit cost for each year is the difference between the annual return of the Jakarta Composite Index and the annual return implicit cost rose sharply in 2015 and 2016, driven in part by the revaluation of PLN assets in 2015. More generally, rising implicit costs at PLN and Pertamina since 2012 have gradually overshadowed the annual net excess returns earned by the other public corporations. The conclusion is similar when comparing the 7-year average of the annual equity-weighted returns of Indonesia's public corporations to the comparable return of the JCI. From January 2010 until December 2016, Indonesia's public corporations had an average ROE of 9.3 percent, well below the average return on the Jakarta Composite Index of 12.4 percent.

\section{Shining light on the implicit costs associated with public corporations could lead to} economy-wide efficiency gains. For example, public corporations often attribute their poor performance to their quasi-fiscal activities - activities undertaken by public corporations at the behest of public authorities that are fiscal, rather than commercial, in nature such as a state-owned electricity distribution company providing an implicit subsidy to consumers by selling electricity at below cost. By explicitly funding these non-commercial activities, the government, as the steward of the public's equity interest in public corporations, would obtain a clearer picture of their ability to generate adequate returns. Funding quasi-fiscal activities from the budget also ensures that the cost of these activities is weighed against

\footnotetext{
15 The return on the Jakarta Composite Index was calculated each year as the percentage change in the end-of-year index value from the preceding end-of-year value.
} 
other spending priorities. More broadly, the implicit costs absorbed by the public sector provides public corporations an advantage that can undermine competition when the public corporation provides goods and services in competitive markets such as power generation and distribution, construction, or banking.

The government could use this analysis to determine how to best utilize its capital. For instance, where public corporations obtain below market returns in commercial sectors, the government should seek to improve their performance, possibly through governance and operational improvements. Failing to do so, the government could explore other options on how best to deploy the public sector's capital. For example, the authorities could sell the public's stake in these companies and use the proceeds to pay down high-cost debt or invest in public goods that generate high social returns. The government could also consider how best to structure its investments to improve the resilience of its balance sheet. Investments in public corporations tend to be illiquid, whereas portfolio investments can be more easily liquidated without a significant loss in value to cover the realization of residual fiscal risk.

\section{Policy Scenario Analysis Using the Intertemporal Balance SheET}

PSBS analysis can inform fiscal policy decisions. Using a public sector intertemporal balance sheet framework, this section illustrates that tax-financed public investment in Indonesia can generate an improvement in public sector net worth of about $6 \frac{1}{2}$ percent of GDP and a permanent increase in the level of real GDP of $1 \frac{1}{3}$ percent. It also shows that improvements in the public investment process can result in even greater increases in public wealth and GDP.

Low public investment limits output growth in Indonesia. The World Bank has estimated that Indonesia faces an infrastructure financing gap of about $\$ 60$ billion a year, with a loss of more than 1 percent of gross domestic product due to under investment in infrastructure (World Bank 2017). In recognition of the shortfall, the authorities announced in 2015 an ambitious infrastructure development plan to be partly funded by higher government revenues.

\section{A. Baseline Scenario}

The baseline intertemporal PSBS combines the static balance sheet with the net present value of future public sector cash flows. The foundation for the baseline intertemporal balance sheet is the static PSBS described in section II above. To this are added projections of the evolution of the balance sheet components for each subsector (general government, non-financial public corporations, and financial public corporations, including the central bank). An intertemporal component - the present value of projected general government revenue and expenditures - is added to derive the public sector intertemporal balance sheet.

The intertemporal component captures public sector cash flow projections for a period of 50 years beyond the static balance sheet year. 
- The evolution of the static PSBS is projected over the period 2017-23. The medium-term general government balance sheet is constructed using IMF staff projections for Indonesia contained in the April 2018 World Economic Outlook (WEO) database. Except for the national oil company (Pertamina), the medium-term balance sheets of the financial- and non-financial public corporations are assumed to evolve in line with nominal GDP. Projections of Pertamina's medium-term balance sheet rest on a pro-forma forecasts of its income statement and balance sheet that reflect the April 2018 WEO oil and gas price projections and simple estimates of domestic and external demand for petroleum products.

- Nominal GDP projections assume productivity increases and the labor participation rate follow long run averages, with changes in the Figure 9. Population Dynamics working age populationunder the UN's medium fertility scenario-driving any changes. ${ }^{16}$ The UN projects Indonesia's population growth rate to slow and turn negative by 2065, as its population ages (See Figure 9). ${ }^{17}$ These anticipated demographic developments generate a projected slowdown in the average annual real GDP growth rate from about 5 percent per annum from 2013-17 to 1.7 percent per annum from 2071-75. The WEO projections for the GDP deflator in 2023 of 3 percent is maintained through the long term, as the output gap is assumed to be closed by 2023 .

- Revenue and expenditures: Most revenue and expenditure items are assumed to move in line with changes in nominal GDP. The baseline assumes that general government revenue stabilizes at its 2023 level of 14.3 percent of GDP. Government expenditures on health and pensions are projected to increase as the population ages. Other discretionary spending (total expenditure net of interest, pension, and health expenditures) is held constant at its 2023 value as a share of GDP. Annex IV shows historical values and

\footnotetext{
${ }^{16}$ See Amaglobeli, D. and W. Shi (2016) for a detailed description of the model.

${ }^{17}$ However, with a projected 3 potential workers for every retiree in 2075, Indonesians will remain a relatively young society.
} 
medium- and long-term baseline projections for the key macroeconomic and fiscal variables, as well as the assumptions behind the projection for each variable.

- Discount rate: The discount rate used to compute the intertemporal component is based on the implicit effective nominal interest rate on general government debt from 20142017, which averaged 5.8 percent This implies a long-run real interest rate under the baseline of 2.7 percent, in line with average real GDP growth over the projection period (roughly 5.8 percent less long-run inflation).

\section{B. Indonesia's Public Sector Intertemporal Net Worth}

\section{Indonesia's public sector intertemporal net worth was slightly positive in 2016. A} positive static net worth offsets the large negative intertemporal component (See Figure 11). Indonesia's primary balances turned negative in 2012 after being positive since at least the mid-1990s, as revenues fell, and expenditures increased relative to GDP. The deterioration in revenue was due in large part to a prolonged decline in oil production that has translated into smaller contributions to general government revenue from the oil and gas sector over time. ${ }^{18}$ Over the medium and long term, the general government primary balance is projected to gradually become more negative in the baseline (Figure 10).

\section{Figure 10. Primary Balance} (Percent of GDP)

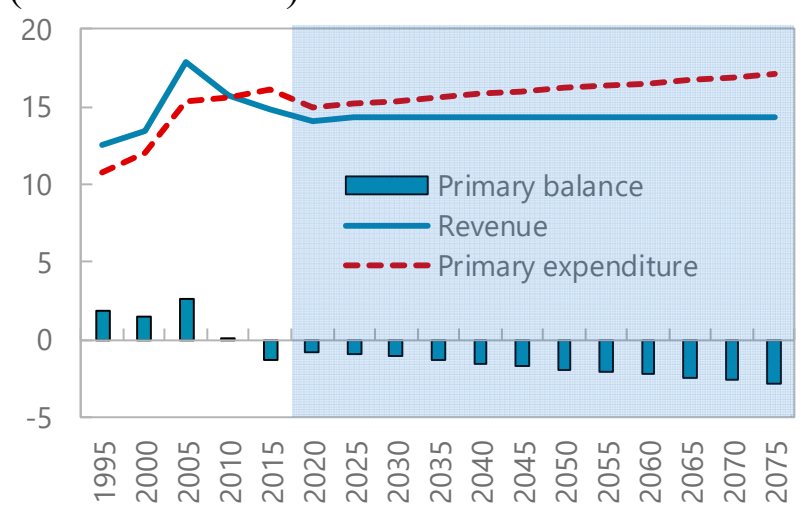

Sources: Indonesia authorities; IMF staff calculations.
Figure 11. Public Sector Intertemporal Net Worth (Percent of GDP)

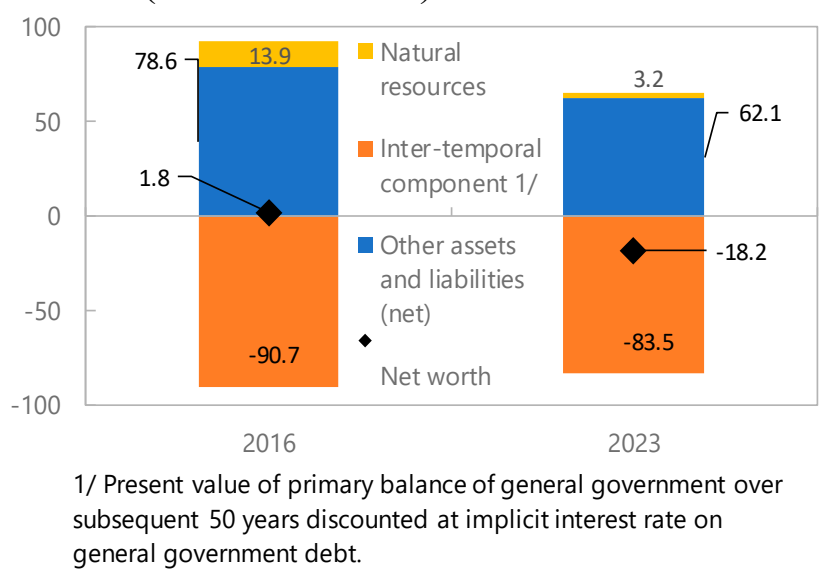

\section{By 2023, the public sector's intertemporal net worth is projected to turn negative} (Figure 11). This implies that current policies do not satisfy the government's intertemporal budget constraint and adjustment is needed. A decrease in natural resource assets relative to GDP drives the projected deterioration in net worth to a negative 18.2 percent in 2023. Also, projected investment by the general government is insufficient to stabilize fixed assets

\footnotetext{
${ }^{18}$ Oil production has fallen steadily from an average of 1.46 million barrels of oil a day in 2000 to an average of 815 thousand barrels a day in 2017.
} 
relative to GDP, given a depreciation rate of 4 percent per annum of the stock of fixed assets (excluding land and oil and mineral reserves). ${ }^{19}$ The fall in static net worth overshadows a narrowing in the net deficit in the intertemporal component relative to GDP. ${ }^{20}$ However, a decomposition of the intertemporal component shows that, in gross terms, the present values of projected revenues and expenditures are several times larger than the stock of assets and liabilities on the static balance sheet in 2023

(Figure 12).
Figure 12. Future Revenues and Expenses, 2023 (Percent of GDP)

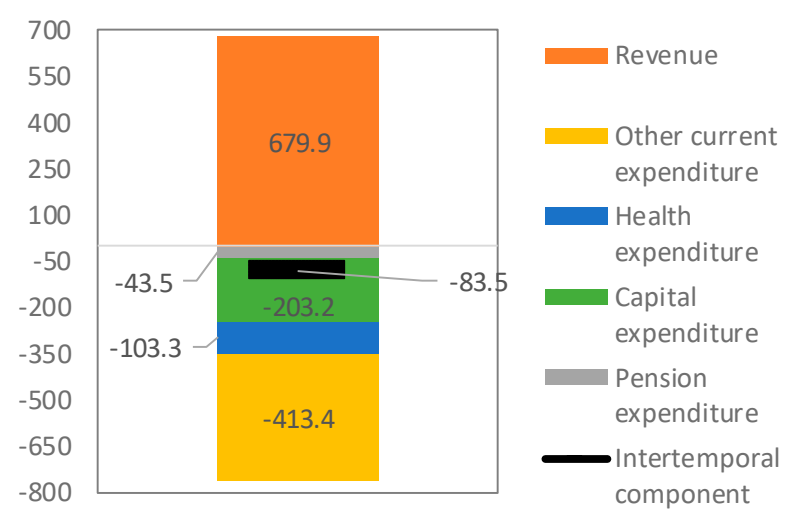

Source: IMF staff estimates.

\section{Sensitivity Tests}

The intertemporal balance sheet is sensitive to assumptions underlying long-run output growth and the real interest rate. Given the uncertainty associated with the long-term projections, a sensitivity analysis of the baseline scenario in 2023 to differing long-run economic growth and real interest rate paths was conducted. Table 2 displays the results.

- Sensitivity to changes in the level or annual growth rate of real GDP: A one-time 10 percent increase (decrease) in the level of real GDP in 2024 generates an absolute improvement (decrease) of 27 percentage points of GDP in the public sector's intertemporal net worth relative to the baseline. A small change in the annual growth rate of real GDP has a much larger effect. An increase (decrease) in the annual growth rate of real GDP for each year of the projection horizon by 0.25 percent, equivalent to a change in the potential growth rate of the same magnitude, generates an absolute improvement (decrease) of about 50 percentage points of GDP in the public sector's intertemporal net worth relative to the baseline

- Sensitivity to the discount rate: As noted earlier, the discount rate used to compute the intertemporal component is the implicit effective nominal interest rate on general government debt. From 2001-17 the average effective nominal rate was 5.8 percent with a standard deviation of 45 basis points. An increase by one standard deviation in the discount rate over the long run, generates an absolute improvement of about 10

\footnotetext{
${ }^{19}$ Depreciation rate of 4 percent is consistent with the depreciation rate used in the modeling of policy scenarios.

${ }^{20}$ The intertemporal component becomes more positive from 2016 to 2023 because nominal GDP growth from 2017-23 exceeds potential growth as the output gap closes, and the long run growth rate is the main driver of changes in the primary balance over the long run.
} 
percentage points of GDP in the public sector's intertemporal net worth relative to the baseline. Conversely, a reduction by one standard deviation in the implicit effective nominal interest rate on general government debt reduces intertemporal net worth by 11 percentage points of GDP.

Table 2. Sensitivity of Baseline Intertemporal Net Worth (Percent of baseline GDP)

\begin{tabular}{|c|c|}
\hline Shock & Change \\
\hline One time 10 percent increase/decrease in the level of real GDP & \pm 27 \\
\hline Increase growth rate of real GDP by 50 basis points & \pm 50 \\
\hline $\begin{array}{l}\text { Increase of one standard deviation in implicit interest rate used to } \\
\text { calculate discount rate }\end{array}$ & +10 \\
\hline $\begin{array}{l}\text { Decrease of one standard deviation in implicit interest rate used to } \\
\text { calculate discount rate }\end{array}$ & -11 \\
\hline
\end{tabular}

Source: IMF staff calculations.

\section{Investment Scenario}

The authorities have targeted an aggressive extension and upgrade of infrastructure in Indonesia. Indonesia's real public capital stock is paltry compared to its neighbors. (Shin, 2018 and Figure 14). In addition, public investment is insufficient to maintain the public capital stock at current levels relative to GDP. To address the infrastructure short fall, the government has identified priority infrastructure projects, with a total cost equivalent to 32 percent of GDP, to be implemented by 2022 (Shin 2018). The general government plans to contribute a tenth of the cost, public corporations about another third, and the private sector the rest.

The Indonesian authorities are developing a medium-term revenue strategy to boost tax revenue (Jin 2018). ${ }^{21}$ Indonesia's tax take is low by international standards (see Figure 13). In addition, general government revenue has fallen over the last decade from about $19 \frac{1}{2}$ percent of GDP in 2008 to 14 percent of GDP in 2017. Declining revenue from a shrinking oil and gas sector accounts for about 60 percent of the decrease. The MTRS envisages a mix of direct and indirect tax rate increases, base-broadening measures, and administrative measures to boost tax revenue over a period of several years.

\footnotetext{
21 An MTRS is a high-level road map of the tax system reform over four to six years, covering policy, administration, and legal components. It is a government-led initiative supported by development partners and private stakeholders aimed at mobilizing tax resources to finance a country's spending needs for economic development and macroeconomic stability.
} 
Figure 13. General Governmnet Tax Revenue (Percent of GDP)

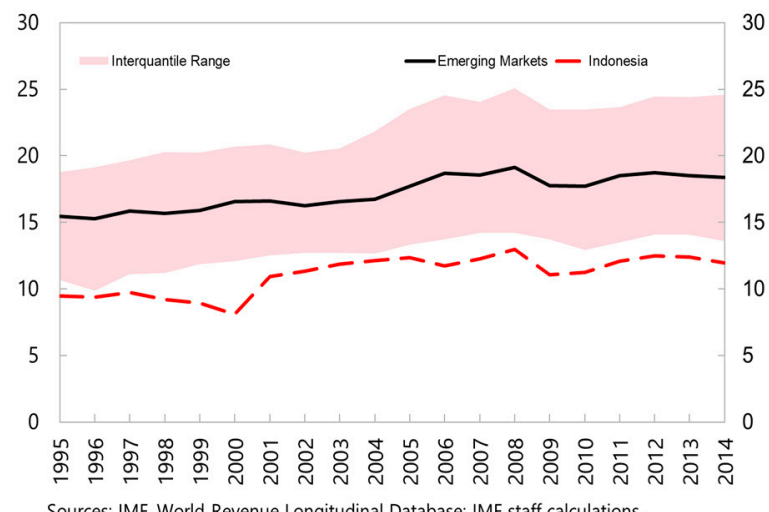

Sources: IMF, World Revenue Longitudinal Database; IMF staff calculations.
Figure 14. General Governmet Real

Capital Stock (Percent of GDP)

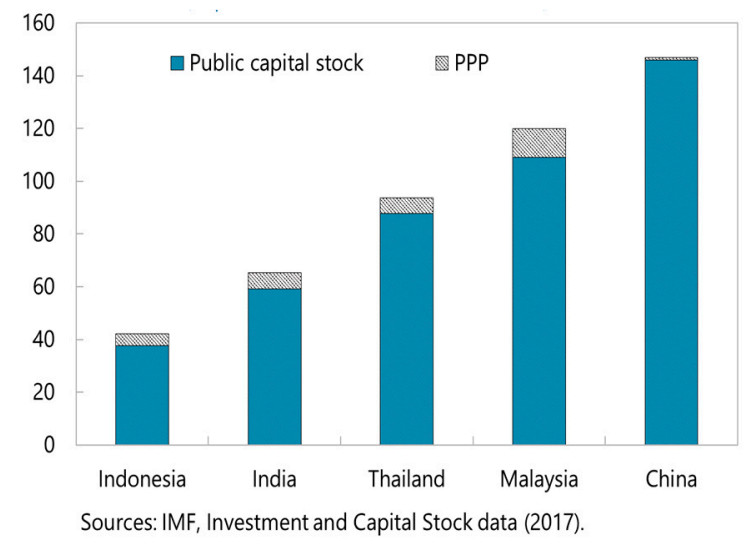

\section{Balance Sheet Analysis of Tax-financed Investment}

Increased public investment financed through higher tax revenue boosts output. Empirical studies find that in advanced economies multipliers of government expenditures are larger than those of taxes (Mineshima and others 2014). Model-based estimates of shortterm multipliers in emerging market and low-income economies suggest that expenditure multipliers are generally larger than revenue multipliers for those economies too (OECD 2009; Ducanes and others 2006). Moreover, Indonesia would derive a boost to growth from higher tax revenues. Gaspar and others (2016) have found that countries with a tax-to-GDP ratio below 15 percent, as in Indonesia, tend to grow slower than countries beyond this tipping point - a phenomenon that is explained by the role of taxation in state building and the strengthening of the social contract with its citizens.

A general equilibrium model is employed to simulate the effects of a tax-financed investment surge on Indonesia's economy. ${ }^{22}$ The model's output feeds into the PSBS framework to provide a comprehensive view of how such a policy would impact Indonesia's public finances. Key model assumptions include:

- General government tax revenues increase by 1 percent of GDP each year from 2019-21 as the government implements its MTRS. The additional tax revenue is sourced roughly evenly from direct and indirect taxes and improved tax administration. The cumulative permanent increase in tax revenue relative to the baseline is 3 percent of GDP.

- The additional tax revenue in 2019-21 finances general government investment. However, only two thirds of the investment spending is assumed to be effective. This is

\footnotetext{
${ }^{22}$ Specifically, the IMF's G20MOD. See Andrle and others (2015) for a full description of the model.
} 
broadly in line with estimates of the effectiveness of public investment spending in emerging markets in general. ${ }^{23}$

- Monetary policy accommodates the fiscal demand stimulus, i.e., the policy rate remains unchanged. ${ }^{24}$ This induces a fall in real interest rates, further supporting an increase in investment relative to the baseline. ${ }^{25}$ The public investment multiplier ranges between 1.2-1.4 in the first couple of years following the incremental investment before gradually fading to zero by 2025 as its persistence wanes.

- From 2022 onwards, the permanently higher tax revenue finances additional health, pension, and education spending, except for a small amount to maintain the new level of the public capital stock, i.e., to offset depreciation of 4 percent per annum on the new capital stock. Other discretionary primary spending (about $1 / 2$ of total spending) is maintained at baseline levels.

\section{Tax-financed public investment increases real GDP in the short, medium, and long}

run. $^{26}$ The level of real GDP rises by $23 / 4$ percent in the short-term relative to the baseline and permanently by $1 \frac{1 / 3}{3}$ percent. ${ }^{27}$ This is a net effect as the drag on growth from additional taxations is taken into account. The permanent increase reflects the boost to potential output from the higher public capital stock (Figure 15).

\footnotetext{
23 "The efficiency score provides a measure of how much output could be increased while holding constant the level of input. It reflects the distance from the efficiency frontier, which is determined by the best performer in a cross-country comparison. It combines data on the volume of economic infrastructure (length of road network, electricity production, and access to water) and social infrastructure (number of secondary teachers and hospital beds)." See Making Public Investment More Efficient. International Monetary Fund, 2015.

24 This assumption is relaxed in the scenario sensitivity analysis below.

25 The increase in the public capital stock also increases the marginal product of capital (e.g., additional infrastructure could reduce transportation costs) potentially stimulating more business investment.

${ }^{26}$ To isolate the impact of policy changes on flows, variations in fiscal projections due to policy changes or shocks are compared to the baseline using the baseline nominal GDP denominator and discount rates.

${ }^{27}$ This is a conservative estimate. The additional spending on health and education following the investment surge would likely boost potential and actual output even more over the long run.
} 
Figure 15. Impact of a Tax-financed Investment (Relative to baseline, percent of baseline GDP)

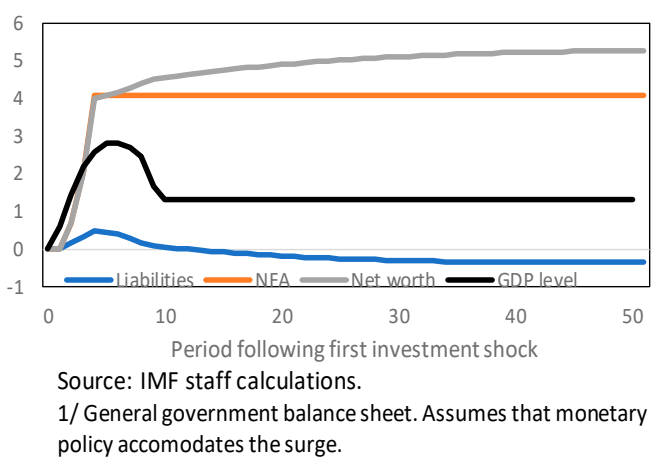

Figure 16. Change in Public Sector Net Worth from Higher Investment (Percent of 2023 baseline GDP)

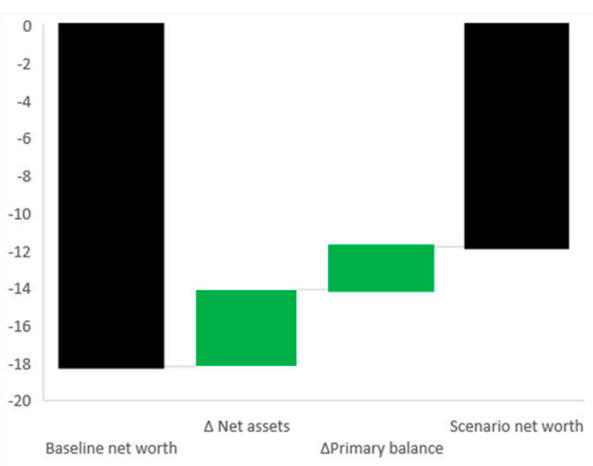

Public sector capital and net worth increase too. This can be seen in changes in the public sector balance sheet in the righthand panel of the figure above. Recall, under the baseline, Indonesia's estimated intertemporal net worth is a negative 18.2 percent of GDP in 2023. The increase in taxed-financed investment from 2019-21 leads to an increase in the general government capital stock of about 4 percent of GDP, and an increase in public sector net assets of the same amount. The additional tax revenues allow for this higher capital stock level to be maintained, supporting a permanently higher output level. The higher output level leads to continuous, albeit modest, improvements in the primary-balance-to-GDP ratio relative to the baseline. As a result, the intertemporal component calculated over a span of fifty years from the time of the initial investment surge increases (i.e., becomes less negative) by about $6 \frac{1}{2}$ percent of GDP.

\section{Comparison of Policy Options}

Structural reforms to enhance the efficiency of public investment would further strengthen growth and net worth. Policymakers can strengthen public investment management to improve the efficiency of investment spending, allowing for higher quality of investment spending within any given budget envelope (Dabla-Norris 2011). Indeed, countries with highly efficient public investment, such as Singapore, get twice the economic return from their investment compared to the least efficient. If Indonesia undertook reforms to strengthen its management of public projects, it would benefit from greater capital stock accumulation for a given level of public investment. For example, if investment efficiency were perfect, Indonesia could increase the level of real GDP even further and add another 3 percentage points of GDP to intertemporal net worth (Table 3, first two columns). 
Table 3. Consolidated Intertemporal Public Sector Net Worth in 2023

(Change from baseline, percent of baseline GDP unless otherwise noted)

\begin{tabular}{|c|c|c|c|c|}
\hline & \multicolumn{2}{|c|}{ Monetary policy accomodation } & \multicolumn{2}{|c|}{ No monetary policy accomodation } \\
\hline & $\begin{array}{l}\text { Tax-financed } \\
\text { investment } 1 /\end{array}$ & $\begin{array}{c}\text { Tax-financed } \\
\text { investment } \\
\text { with structural } \\
\text { reforms 2/ } \\
\end{array}$ & $\begin{array}{c}\text { Tax-financed } \\
\text { investment } 1 / 3 /\end{array}$ & $\begin{array}{c}\text { Debt-financed } \\
\text { investment 1/ 3/ }\end{array}$ \\
\hline $\begin{array}{l}\text { Long-run level of real GDP } \\
\text { (percent of baseline) }\end{array}$ & 1.3 & 2.2 & 0.5 & 1.0 \\
\hline Net assets (including capital stock) & 4.2 & 6.3 & 3.1 & -1.4 \\
\hline PV of primary balance & 2.2 & 3.5 & 1.2 & 2.3 \\
\hline Net worth 4/ & 6.5 & 9.7 & 4.5 & 0.9 \\
\hline
\end{tabular}

Source: IMF staff calculations.

$1 /$ Assumes investment efficiency of 0.67.

2/ Assumes full investment efficiency.

3 / Interest rate on general government debt adjusts with changes in policy rate, but assume no change in interest premia due to higher debt levels. Interest rates on debt return to baseline rate by 2028.

$4 /$ Components do not sum to change in net worth do to rounding.

Tax-financed public investment generates a higher public net worth compared to debtfinanced investment. For comparing the tax- and debt-financed scenarios, we assume monetary policy does not accommodate the investment surge. With this assumption, the change in net worth relative to the baseline from financing public investment with a mix of direct and indirect taxes and improved tax administration is still positive at 4.5 percent (though lower than the scenario assuming monetary policy accommodation), while the change is about 1 percent of GDP with debt financing (Table 3). ${ }^{28}$ The difference occurs mainly because debt financing creates a liability that offsets the increase in the capital stock. In addition, the policy interest rate increases more in the debt-financed scenario to offset the greater demand stimulus. This leads to a greater accumulation of liabilities as the higher interest payments add to the debt stock. More broadly, all the scenarios probably understate the overall improvement in Indonesians' well-being as the scenarios do not account for the likely increase in private wealth due to the increase in public investment.

\footnotetext{
28 The additional investment (maintenance) required to offset depreciation on the higher capital stock is "absorbed" by reducing other expenditures by an equivalent amount.
} 


\section{Investment scenario sensitivity to monetary policy assumptions}

The monetary policy stance can significantly influence the magnitude of the responses of the economy and the PSBS to a tax-financed investment surge. The investment scenario presented above assumes that the monetary policy rate does not change in response to the demand stimulus and pickup in inflation from the tax-financed investment. If the monetary policy authorities were to raise the policy rate sufficient to keep real interest rates essentially unchanged (i.e., no monetary policy
Figure 17. Real GDP Level

(Percent difference from baseline)

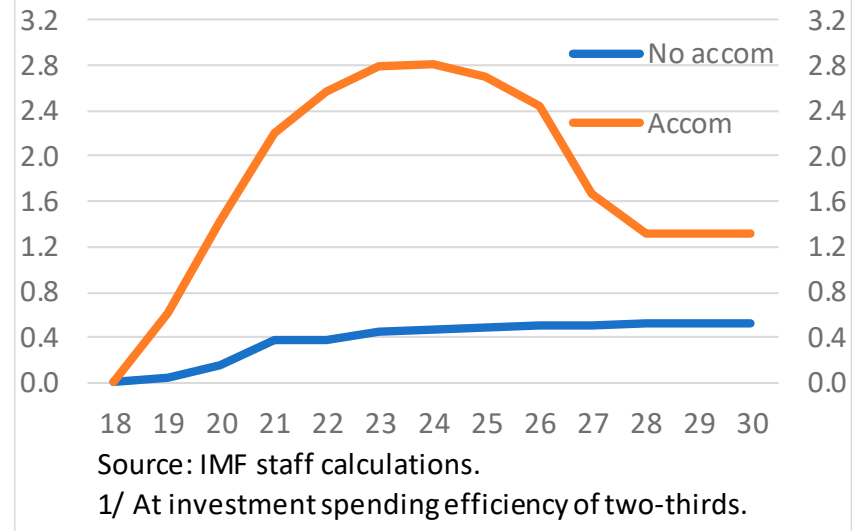
accommodation), the level of real GDP would increase about $1 / 2$ percent over the baseline level in both the short and long run (Figure 17). The net worth also increases less. While the increase in the public sector net assets (4 percent of GDP) is about the same, the improvement in the intertemporal component (1.2 percent of GDP) leads to smaller improvement in intertemporal net worth of $4 \frac{1}{2}$ percent of GDP vs. $6 \frac{1}{2}$ percent when monetary policy is accommodative. ${ }^{29}$ The monetary authorities may choose a nonaccommodative policy stance given vulnerabilities to foreign exchange depreciation and reliance on foreign capital flows.

\section{Conclusion}

Indonesia's public sector balance sheet is large but shrinking. Public assets were 166 percent of GDP in 2016 with natural resources and public corporations comprising significant components. With fewer liabilities, public sector wealth was positive. However, it is expected to turn negative over the medium term as natural resources are gradually depleted.

This paper contributes to the growing literature on applying the public sector balance sheet approach to fiscal policy analyses. The high-level risk assessment reveals that some of Indonesia's non-financial public corporations pose a fiscal risk. To manage the risk, the authorities should consider governance and operational reforms with an eye to making public corporations more commercially viable. The paper also shows how the public sector balance

\footnotetext{
${ }^{29}$ Under the no monetary policy accommodation scenario, G20MOD projects the policy interest rate to increase an average of 60 basis points during the investment surge years of 2019-21 and then taper back to the base line level by 2024 .

However, the baseline discount rate was used to calculate the intertemporal component for this scenario. If the discount rate were adjusted for the change in interest rates, the positive change in intertemporal net worth for the "no accommodation" scenario would have been less.
} 
sheet approach can be applied to assess the economic and public net worth implications of policy considerations such as the Indonesian government's infrastructure development plans. An intertemporal balance sheet analysis shows that a tax-financed investment strategy in Indonesia can boost both the level of GDP and public sector wealth over the long run. It also highlights that measures to improve the public investment process can yield considerable additional gains in terms of GDP and public wealth. 


\section{REFERENCES}

Andrle, M., P. Blagrave, P. Espaillat, K. Honjo, B. Hunt, M. Kortelainen, R. Lalonde, D. Laxton, E. Mavroeidi, D. Muir, S. Mursula, and S. Snudden. 2015. "The Flexible System of Global Models_-FSGM.” IMF Working Paper 15/64, International Monetary Fund, Washington, DC.

Amaglobeli, D., and W. Shi. 2016. "How to Assess Fiscal Implications of Demographic Shifts: A Granular Approach." IMF How-To-Note 16/02, International Monetary Fund, Washington, DC.

Dabla-Norris, E., J. Brumby, A. Kyobe, Z. Mills, and C. Papageorgiou. 2011. "Investing in Public Investment: An Index of Public Investment Efficiency.” IMF Working Paper 11/37, International Monetary Fund, Washington, DC.

Ducanes, G., M. Cagas, D. Qin, P. Quising, and M. Razzaque. 2006. “Macroeconomic Effects of Fiscal Policies: Empirical Evidence from Bangladesh, China, Indonesia, and the Philippines." Macroeconomic Effects of Fiscal Policies:... (PDF Download $\underline{\text { Available) }}$

Holston, K., T. Laubach, and J. Williams. 2017. "Measuring the natural rate of interest: International trends and determinants." Journal of International Economics 108: S59S75.

Gaspar V., L. Jaramillo, and P. Wingender. 2016. “Tax Capacity and Growth: Is There a Tipping Point?” IMF Working Paper 16/234, International Monetary Fund, Washington, DC.

International Monetary Fund (IMF). 2014. World Economic Outlook: Is It Time for an Infrastructure Push? The Macroeconomic Effects of Public Investment. Chapter 3, Washington.

—. 2017. Country Report 17/152: Financial System Stability Assessment. Washington.

- 2018a. 2017 Country Report 18/32: Article IV Consultation. Washington.

_. 2018b. Fiscal Monitor: Managing Public Wealth. Washington, October.

Jin, H. 2018. "Prioritizing Fiscal Reforms to Enhance Productivity and Equity in Indonesia." Indonesia: Selected Issues, IMF Country Report 18/33, Washington: International Monetary Fund.

Mineshima, A., M. Poplawski-Ribeiro, and A. Weber. 2014. "Size of Fiscal Multipliers Post-Crisis Fiscal Policy, organized by C. Cottarelli, P. Gerson, and A. Senhadji, Chapter III.12, Cambridge, MIT Press: 315-72. 
Organization of Economic Cooperation and Development. 2009. The Effectiveness and Scope of Fiscal Stimulus, in OECD Economic Outlook Interim Report, pp. 105-50, Paris: Organization of Economic Cooperation and Development.

De Mooij, R., S. Nazara, and J. Toro. 2018. "Implementing a Medium-Term Revenue Strategy.” Realizing Indonesia's Economic Potential. Editors: L. E. Breuer, J. Guajardo, and T. Kinda. International Monetary Fund. Washington, DC.

Shin, J. 2018. "Indonesia’s Growth Strategy: Boosting Potential Growth with Structural Reforms.” Indonesia: Selected Issues, IMF Country Report 18/33, Washington: International Monetary Fund.

Standard \& Poor's Rating Services. 2011. Banks: Rating Methodology and Assumptions www.standardandpoors.com/ratingsdirect

—. 2013. Corporate Methodology www.standardandpoors.com/ratingsdirect

United Nations, Department of Economic and Social Affairs, Population Division. 2017. World Population Prospects: The 2017 Revision. 


\section{ANNEX I}

\section{Mineral And Energy Resources-Methodology of Calculation}

Country estimates for mineral and energy resources are often based on various estimation techniques. Not many countries disseminate such data. To attain consistency, the PSBS dataset follows the GFSM 2014 valuation guidelines to estimate these values. Estimates for the stock of mineral and energy resources in the PSBS database correspond to the net present value of the expected pre-tax cash flows resulting from their commercial exploitation. Sources and methods for these estimates differ by type of commodity, and the choice of estimation method was largely determined by the availability of source data and attempts to consider country specific economic conditions in these estimations. ${ }^{30}$

The value of stocks of oil and gas were estimated using the following data sources: (1.1) production over the lifetime of the asset, from the Rystad database (Rystad Energy 2018); (1.2) prices (in US\$) from WEO forecasts available at the end of the reference year; (1.3) costs of production (in US\$), from the Rystad database; and (1.4) exchange rates, from WEO forecasts available at the end of the reference year.

Sources 1.1, 1.2, and 1.3 were used to calculate future US\$ cash flows over an 85-year horizon. These US\$ cash flows were converted to domestic currency using WEO exchange rate forecasts (source 1.4). The net present value of the domestic currency cash flows was calculated using a discount rate equivalent to the average (2000-22) long-term (10-year) government bond yields in WEO plus a risk factor (one percent for advanced economies, three percent for emerging economies, six percent for low-income developing countries). When WEO government bonds were not available, the central bank policy rate plus 5 percent was used.

The value of stocks of coal, metals and other minerals were estimated using the following data sources: (2.1) estimates (in constant 2014 US\$ prices), from the World Bank's "The Changing Wealth of Nations 2018" report (Lange and others 2018); (2.2) United States Geological Survey data on 2016 reserves and 2014-16 production by commodity and by country (Wilburn and others 2016), where available; (2.3) prices (in US\$) from WEO commodity prices for 2000-16; (2.4) exchange rates, from the current vintage of WEO exchange rates.

Estimates for 2015 and 2016 are based on the changes in reserves in those years, for those commodities for which reserve data are available (source 2.2). Where these are not available (usually cases where reserves for a particular commodity are relatively small), the assumption was that the value of the stocks is unchanged from 2014 onward. The obtained

\footnotetext{
${ }^{30}$ PSBS database estimates differ from the World Bank's "The Changing Wealth of Nations 2018" report because the World Bank uses a discount rate of $4 \%$ for all countries and constant value data for prices, whereas the PSBS dataset use different vintages of commodity-specific prices from WEO reports.
} 
estimates based on the constant 2014 US\$ prices were converted to current US\$ prices using the price index obtained through WEO commodity prices (source 2.3), and subsequently converted to domestic currency using WEO exchange rates (source 2.4).

For countries where subsoil assets can be owned by units other than government, the calculated estimates were pro-rated using alternative (country-specific) indicators on ownership of land under which the mineral and energy resources lie. Where such countryspecific adjustments occurred, it is revealed in the database documentation. 
ANNEX II

Annex II. Table 1. 2016 Indonesia Public Sector Balance Sheet (Percent of GDP)

\begin{tabular}{|c|c|c|c|c|c|}
\hline GOVERNMENT BALANCE SHEET & $\begin{array}{c}\text { General } \\
\text { Government }\end{array}$ & $\begin{array}{l}\text { Non-Financial } \\
\text { Public } \\
\text { Corporations }\end{array}$ & $\begin{array}{c}\text { Financial Public } \\
\text { Corporations }\end{array}$ & Public Sector & Consolidation \\
\hline Total assets & 123.8 & 26.3 & 39.6 & 165.6 & -24.1 \\
\hline Nonfinancial assets & 95.8 & 20.0 & 1.0 & 116.8 & 0.0 \\
\hline Fixed assets & 19.1 & 16.8 & 0.4 & 36.4 & 0.0 \\
\hline Other produced assets & 1.0 & 1.3 & 0.0 & 2.3 & 0.0 \\
\hline Land & 15.5 & 1.9 & 0.5 & 17.9 & 0.0 \\
\hline Mineral and energy resources & 60.2 & 0.0 & 0.0 & 60.2 & 0.0 \\
\hline Permits to use natural resources & 0.0 & 0.0 & 0.0 & 0.0 & 0.0 \\
\hline Other non-produced assets & 0.0 & 0.0 & 0.0 & 0.0 & 0.0 \\
\hline Financial assets & 28.0 & 6.4 & 38.6 & 48.8 & -24.1 \\
\hline by instrument & 0.0 & 0.0 & 0.0 & 0.0 & 0.0 \\
\hline Monetary gold and SDRs & 0.0 & 0.0 & 0.6 & 0.6 & 0.0 \\
\hline Currency and deposits & 3.6 & 2.7 & 4.4 & 8.4 & -2.4 \\
\hline Debt securities & 0.0 & 0.5 & 16.7 & 12.4 & -4.7 \\
\hline Loans & 0.9 & 0.0 & 15.6 & 14.9 & -1.6 \\
\hline Equity and investment fund shares & 20.2 & 0.2 & 0.2 & 6.4 & -14.3 \\
\hline Insurance, pension, and standardized guarantee schemes & 0.0 & 0.0 & 0.0 & 0.0 & 0.0 \\
\hline Financial derivatives and employee stock options & 0.0 & 0.0 & 0.2 & 0.2 & 0.0 \\
\hline Other accounts receivable & 3.2 & 3.0 & 0.9 & 5.9 & -1.2 \\
\hline Liabilities & 31.3 & 26.3 & 39.6 & 73.1 & -24.1 \\
\hline by instrument & 0.0 & 0.0 & 0.0 & 0.0 & 0.0 \\
\hline SDRs & 0.0 & 0.0 & 0.3 & 0.3 & 0.0 \\
\hline Currency and deposits & 0.0 & 0.0 & 27.3 & 24.9 & -2.4 \\
\hline Debt securities & 23.0 & 2.4 & 2.3 & 23.0 & -4.7 \\
\hline Loans & 5.5 & 3.6 & 1.1 & 8.7 & -1.6 \\
\hline Equity and investment fund shares & 0.0 & 14.4 & 5.8 & 6.0 & -14.3 \\
\hline Insurance, pension, and standardized guarantee schemes & 0.0 & 0.0 & 1.9 & 1.9 & 0.0 \\
\hline Pension entitlements & 0.0 & 0.0 & 1.9 & 1.9 & 0.0 \\
\hline Claims of pension fund on pension managers & 0.0 & 0.0 & 0.0 & 0.0 & 0.0 \\
\hline Other & 0.0 & 0.0 & 0.0 & 0.0 & 0.0 \\
\hline Financial derivatives and employee stock options & 0.0 & 0.0 & 0.1 & 0.1 & 0.0 \\
\hline Other accounts payable & 2.8 & 5.9 & 0.7 & 8.2 & -1.2 \\
\hline NET FINANCIAL WORTH & -3.3 & -20.0 & -1.0 & -24.3 & 0.0 \\
\hline NET WORTH & 92.5 & 0.0 & 0.0 & 92.5 & 0.0 \\
\hline
\end{tabular}


ANNEX III

Annex III. Table 1. Indonesia: Large Public Corporations-Select Financial Information 1/

\begin{tabular}{|c|c|c|c|c|c|c|c|c|}
\hline Public corporation & Common name & Sector & Assets & Equity & Profitability $2 /$ & Liquidity $3 /$ & Solvency 4/ & Other $5 /$ \\
\hline Financial & & & \multicolumn{2}{|c|}{$\underline{(\text { Percent of GDP) }}$} & $\underline{\mathrm{ROA}}$ & Loan/deposit & $\begin{array}{c}\text { Capital } \\
\text { adequacy }\end{array}$ & $\underline{\text { NPL ratio }}$ \\
\hline PT Bank Mandiri (Persero) Tbk & Bank Mandiri & Banking & 8.37 & 1.24 & 2.2 & 82.5 & 14.8 & 4.2 \\
\hline PT Bank Rakyat Indonesia (Persero) Tbk & BRI & Banking & 8.09 & 1.18 & 3.1 & 84.9 & 14.6 & 2.2 \\
\hline PT Bank Negara Indonesia (Persero) Tbk & $\mathrm{BNI}$ & Banking & 4.86 & 0.72 & 2.1 & 86.5 & 14.8 & 3.0 \\
\hline PT Bank Tabungan Negara (Persero) Tbk & BTN & Banking & 1.73 & 0.15 & 1.1 & 101.5 & 8.9 & 2.8 \\
\hline PT TASPEN (Persero) & Taspen & Insurance & 0.26 & 0.24 & 0.1 & $\mathrm{n} / \mathrm{a}$ & $\mathrm{n} / \mathrm{a}$ & $\mathrm{n} / \mathrm{a}$ \\
\hline Total financial & & & 23.3 & 3.5 & & & & \\
\hline Nonfinancial & & & & & $\underline{\mathrm{ROE}}$ & $\underline{\text { Current ratio }}$ & Debt ratio & Debt/EBITDA \\
\hline PT Perusahaan Listrik Negara (Persero) & PLN & Electricity supply & 9.46 & 0.14 & -1.1 & 0.83 & 44.7 & 4.6 \\
\hline PT Pertamina & Pertamina & Oil and gas & 3.36 & 0.26 & 1.1 & 2.00 & 114.0 & 29.3 \\
\hline PT Telekomunikasi Indonesia Tbk & Telkom & Telecommunications & 1.06 & 0.00 & 26.3 & 1.20 & 70.2 & 0.5 \\
\hline PT Pupuk Indonesia (Persero) & Pupuk & Fertilizer & 0.62 & 0.00 & 14.6 & 1.17 & 108.7 & 6.7 \\
\hline PT Perusahaan Gas Negara (Persero) Tbk & PGN & Natural gas distribution & 0.51 & 0.03 & 23.7 & 2.61 & 115.6 & 5.7 \\
\hline PT Krakatau Steel (Persero) Tbk & Krakatau Steel & Steel & 0.32 & 0.00 & 3.8 & 0.81 & 114.0 & loss \\
\hline PT Garuda Indonesia (Persero) Tbk & Garuda Indonesia & Aviation & 0.28 & 0.00 & -2.1 & 0.75 & 270.1 & 24.9 \\
\hline PT Waskita Karya (Persero) & Waskita & Construction & 0.20 & 0.05 & 13.4 & 1.17 & 266.2 & 6.0 \\
\hline Total nonfinancial & & & 15.8 & 0.5 & & & & \\
\hline
\end{tabular}

Memo:

Nominal GDP (IDR - millions)

$12,406,810$

Sources: Company financial statements; IMF staff calculations.

1/ For financial year ending in 2016 (unless otherwise noted).

2/ Five year averages; ROA = return on assets; ROE = return on equity

3/ Loan/deposit - ratio of client loans to client deposits; current ratio = ratio of current assets to current liabilities.

4/ Capital adequacy (Total capital adequacy) $=$ ratio of risk-weighted assets to total capital; debt ratio $=$ total liabilities divided by total assets

5/ NPL ratio = non-performing loans divided by total loans; Debt/EBITDA = loans and borrowings divided by earnings before interest, tax, depreciation, and amortization. 


\section{Annex IV}

Annex IV. Table 1. Indonesia Public Sector Balance Sheet: Baseline Assumptions

\begin{tabular}{|c|c|c|c|c|c|c|c|c|c|c|c|c|c|c|c|c|}
\hline & 2014 & 2015 & 2016 & 2017 & 2018 & 2019 & 2020 & 2021 & 2022 & 2023 & 2025 & 2030 & 2040 & 2050 & 2100 & Assumptions \\
\hline Economy & \multicolumn{15}{|c|}{ (Percent change) } & \multirow[b]{2}{*}{ MT: WEO scenario; LT: growth accounting } \\
\hline Real GDP & 5.0 & 4.9 & 5.0 & 5.1 & 5.3 & 5.5 & 5.6 & 5.6 & 5.6 & 5.6 & 3.0 & 2.8 & 2.4 & 2.0 & 2.0 & \\
\hline Nominal GDP & 10.7 & 9.1 & 7.6 & 9.5 & 9.0 & 9.0 & 9.4 & 9.2 & 8.9 & 8.8 & 6.1 & 5.9 & 5.4 & 5.1 & 5.0 & MT: WEO scenario; LT: calculated \\
\hline Non-oil & 11.7 & 11.3 & 9.2 & 8.7 & 8.6 & 10.3 & 10.2 & 9.6 & 9.3 & 9.1 & 6.1 & 5.9 & 5.4 & 5.1 & 5.0 & MT: WEO scenario; LT: calculated \\
\hline Oil & 0.5 & -17.6 & -16.4 & 26.7 & 16.7 & -13.1 & -8.3 & -2.9 & -1.2 & -0.3 & 6.1 & 5.9 & 5.4 & 5.1 & 5.0 & MT: WEO scenario; LT: calculated \\
\hline Deflator & 5.4 & 4.0 & 2.5 & 4.2 & 3.5 & 3.3 & 3.6 & 3.4 & 3.1 & 3.0 & 3.0 & 3.0 & 3.0 & 3.0 & 3.0 & MT: WEO scenario; LT: set at 2023 value \\
\hline External demand & 3.7 & 2.2 & 2.4 & 6.4 & 5.6 & 5.7 & 5.0 & 4.4 & 4.1 & 3.9 & 3.9 & 3.9 & 3.9 & 3.9 & 3.9 & MT: WEO scenario; LT: set at 2023 value \\
\hline IDN/USD rate (average, $+=$ depr) & 13.9 & 12.9 & -0.6 & 0.6 & 3.0 & 1.6 & 1.0 & 1.6 & 1.3 & 1.2 & 0.0 & 0.0 & 0.0 & 0.0 & 0.0 & MT: WEO scenario; $L T$ : assumed to be zero \\
\hline WEO oil price (USD/barrel) & -7.5 & -47.2 & -15.7 & 23.3 & 18.0 & -6.5 & -4.6 & -2.7 & -1.0 & 0.1 & 2.0 & 2.0 & 2.0 & 2.0 & 2.0 & MT: WEO scenario; LT: assumed to be two percent \\
\hline Indonesia oil price (USD/barrel) & -8.3 & -50.1 & -16.6 & 19.5 & 20.9 & -6.5 & -4.6 & -2.7 & -1.0 & 0.1 & 2.0 & 2.0 & 2.0 & 2.0 & 2.0 & MT: WEO scenario; LT: same as LT oil price assumption \\
\hline WEO natural gas price & -3.0 & -33.2 & -34.5 & 16.4 & 11.7 & -7.5 & -4.0 & -0.6 & -0.8 & 1.2 & 2.0 & 2.0 & 2.0 & 2.0 & 2.0 & MT: WEO scenario; LT: same as LT oil price assumption \\
\hline Discount rate & 5.6 & 6.0 & 5.8 & 6.2 & 6.1 & 6.0 & 6.0 & 5.9 & 5.8 & 5.8 & 5.8 & 5.8 & 5.8 & 5.8 & 5.8 & MT: WEO implicit rate (interest/gross debt); LT: average rate, 2014-16 \\
\hline General government & \multicolumn{15}{|c|}{ (Percent of GDP) } & \\
\hline Revenue & 16.5 & 14.9 & 14.3 & 14.0 & 14.2 & 14.1 & 14.0 & 14.1 & 14.2 & 14.3 & 14.3 & 14.3 & 14.3 & 14.3 & 14.3 & MT: WEO scenario; LT: calculated \\
\hline Non-SOE taxes & 11.6 & 11.5 & 11.1 & 10.7 & 10.8 & 10.9 & 10.9 & 11.1 & 11.1 & 11.3 & 11.3 & 11.3 & 11.3 & 11.3 & 11.3 & MT: WEO scenario; LT: set at 2023 ratio \\
\hline SOE taxes & 0.4 & 0.5 & 0.4 & 0.4 & 0.4 & 0.4 & 0.4 & 0.4 & 0.4 & 0.4 & 0.4 & 0.4 & 0.4 & 0.4 & 0.4 & MT and LT: GFSM 2016 amount multiplied by nominal GDP growth 1/ \\
\hline SOE dividend & 0.7 & 0.3 & 0.1 & 0.2 & 0.1 & 0.1 & 0.1 & 0.1 & 0.1 & 0.1 & 0.1 & 0.1 & 0.1 & 0.1 & 0.1 & MT and LT: GFSM 2016 amount multiplied by nominal GDP growth 1/ \\
\hline SOE interest & 0.4 & 0.5 & 0.4 & 0.4 & 0.4 & 0.4 & 0.4 & 0.4 & 0.4 & 0.4 & 0.4 & 0.4 & 0.4 & 0.4 & 0.4 & MT and LT: GFSM 2016 amount multiplied by nominal GDP growth \\
\hline Non-tax oil \& gas (ex dividends) & 2.1 & 0.7 & 0.4 & ... & $\ldots$ & $\ldots$ & $\ldots$ & $\ldots$ & $\ldots$ & $\ldots$ & $\ldots$ & $\ldots$ & $\ldots$ & $\ldots$ & $\ldots$ & MT and LT: Receipts gradually return to 1/4 of oil GDP by 2024 . \\
\hline Other & 1.3 & 1.5 & 1.9 & 1.8 & 1.7 & 1.6 & 1.5 & 1.5 & 1.5 & 1.4 & 1.4 & 1.4 & 1.4 & 1.4 & 1.4 & MT: WEO scenario; LT: set at 2023 ratio \\
\hline Expenditure & 18.6 & 17.5 & 16.8 & 16.5 & 16.7 & 16.6 & 16.5 & 16.6 & 16.7 & 16.8 & 16.9 & 17.4 & 18.7 & 20.4 & 21.3 & MT: WEO scenario; LT: calculated \\
\hline Health & $\ldots$ & 1.3 & 1.3 & 1.3 & 1.3 & 1.3 & 1.4 & 1.4 & 1.4 & 1.4 & 1.5 & 1.6 & 1.9 & 2.3 & 2.4 & MT and LT: growth accounting from demographics template \\
\hline Pension & $\ldots$ & 0.5 & 0.5 & 0.5 & 0.5 & 0.6 & 0.6 & 0.6 & 0.6 & 0.6 & 0.7 & 0.7 & 0.9 & 0.9 & 1.0 & MT and LT: based on UN pop proj;; adjusted for existing pension liabilities \\
\hline Interest & 1.3 & 1.4 & 1.5 & 1.6 & 1.6 & 1.6 & 1.6 & 1.7 & 1.7 & 1.7 & 1.8 & 2.1 & 3.0 & 4.2 & 5.0 & MT: WEO scenario; LT: calculated using implicit rate at end 2023 \\
\hline Subsidies & 3.7 & 1.6 & 1.4 & 1.4 & 1.3 & 1.3 & 1.3 & 1.3 & 1.3 & 1.3 & 1.3 & 1.2 & 1.2 & 1.2 & 1.2 & MT and LT: GFSM 2016 amount multiplied by nominal GDP growth 1/ \\
\hline Other current & 10.6 & 9.2 & 8.6 & 7.9 & 8.1 & 7.9 & 7.9 & 7.8 & 7.6 & 7.5 & 7.5 & 7.5 & 7.5 & 7.5 & 7.5 & MT: WEO scenario; LT: set at 2023 ratio \\
\hline Acquisition of NFAs & 3.1 & 3.6 & 3.6 & 3.8 & 3.7 & 3.8 & 3.8 & 3.9 & 4.1 & 4.3 & 4.3 & 4.3 & 4.3 & 4.3 & 4.3 & MT: WEO scenario; LT: set at 2023 ratio; stock revalued by GDP deflator \\
\hline Net lending/borrowing & -2.1 & -2.6 & -2.5 & -2.5 & -2.5 & -2.5 & -2.5 & -2.5 & -2.5 & -2.5 & -2.6 & -3.1 & -4.5 & -6.1 & -7.0 & MT: WEO scenario; LT: calculated \\
\hline Net acquisition of FA & 0.3 & 0.7 & 0.7 & 0.6 & 0.4 & 0.4 & 0.4 & 0.3 & 0.3 & 0.3 & 0.3 & 0.3 & 0.3 & 0.3 & 0.3 & MT: WEO scenario; LT: set at 2023 ratio \\
\hline Net incurrence of liabilities & 2.5 & 3.3 & 3.2 & 3.1 & 2.9 & 2.9 & 2.9 & 2.8 & 2.8 & 2.8 & 2.9 & 3.4 & 4.8 & 6.4 & 7.4 & MT: WEO scenario; LT: calculated \\
\hline \multicolumn{17}{|l|}{ Memoranda } \\
\hline$(\mathrm{r}-\mathrm{g})$ (percentage & -5.1 & -3.1 & -1.9 & -3.4 & -2.9 & -3.0 & -3.4 & -3.3 & -3.1 & -3.0 & -0.3 & -0.1 & 0.3 & 0.7 & 0.7 & MT: WEO scenario; LT: calculated \\
\hline Primary balance (percent of GDP) & -0.9 & -1.2 & -1.0 & -0.9 & -0.9 & -0.8 & -0.8 & -0.8 & -0.8 & -0.8 & -0.9 & -1.1 & -1.5 & -1.9 & -2.1 & MT: WEO scenario; LT: calculated \\
\hline Oil GDP as a share of total GDP & 7.9 & 6.0 & 4.6 & 5.4 & 5.8 & 4.6 & 3.8 & 3.4 & 3.1 & 2.8 & 2.8 & 2.8 & 2.8 & 2.8 & 2.8 & MT: WEO scenario; LT: set at 2023 ratio \\
\hline
\end{tabular}

$\begin{array}{llllllll}1 / \text { Pertamina's taxes, dividiends, and subsidies based on various operating and financial assumptions. } & \text {. }\end{array}$ 